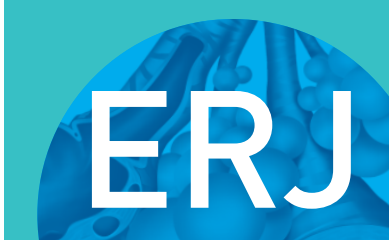

open research

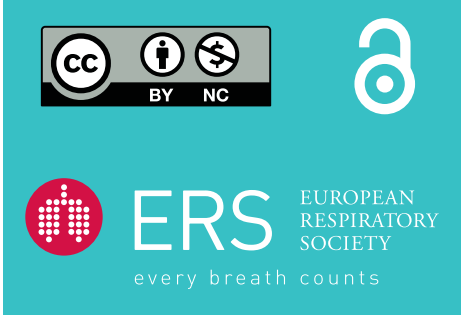

\section{No association between human herpesvirus or herpesvirus saimiri and idiopathic pulmonary fibrosis}

\author{
To the Editor:
}

Idiopathic pulmonary fibrosis (IPF) is a rare, progressive and irreversible lung disease leading to death within 3 to 5 years of diagnosis [1]. The current hypothesis concerning pathophysiology is that chronic alveolar epithelial cell injury leads to an aberrant reparative response resulting in chronic architecture remodelling of the lung. By inducing alveolar cell injury, viral infection or reactivation has been proposed to play a role in the pathogenesis of IPF and could act as a trigger for acute exacerbation [2]. Herpesviruses are particular suspects since a higher prevalence of Epstein-Barr virus (EBV) and human herpesvirus 8 (HHV-8) has been identified in lung samples from IPF patients [2-7]. However, many of these studies were performed in a period where steroids and immunosuppressive drugs were the standard of care for IPF patients. Mouse models have also suggested the involvement of human herpesviruses as an enhancer of the fibrotic response in lung, by inducing pro-fibrotic factors [8]. Herpesvirus saimiri (HVS), a nonpathogenic gamma herpesvirus infecting squirrel monkeys, has been associated with IPF in one study [9]. This finding has not been confirmed yet. The role of torque teno virus (TTV) has been previously suspected in acute exacerbation of IPF [10].

The aim of this study was to assess the presence of TTV, HVS and human herpesviruses DNA, using realtime PCR assays, in lung samples from IPF and control patients to evaluate their potential role in IPF pathogenesis.

Lung samples were obtained from 19 IPF patients (median (interquartile range (IQR)) age 58.0 (51-62) years), at time of diagnosis $(n=1)$ or lung transplant $(n=18)$ (table 1). IPF was diagnosed according to 2011 American Thoracic Society/European Respiratory Society/Japanese Respiratory Society/ Latin American Thoracic Association criteria. 13 patients were receiving antifibrotic drugs (pirfenidone $\mathrm{n}=10$, nintedanib $\mathrm{n}=3)$, in combination with prednisone $\left(<10 \mathrm{mg} \cdot \mathrm{day}^{-1}\right)$ in one patient; one patient received prednisone alone $\left(<10 \mathrm{mg} \cdot \mathrm{day}^{-1}\right)$; and five patients received no specific treatment. Lung samples used as controls were obtained after cancer surgery, away from the tumour, for seven patients, and at time of lung transplant for two patients presenting evolved COPD (median (IQR) age 69 (60.0-71.0) years). All controls were free of systemic corticosteroids or immunosuppressive drugs at time of surgery. Populations were comparable for smoking status and environmental exposure, but there were significantly more females in the control group (4/9 (44.4\%) versus $2 / 19$ (10.5\%)), and this group was slightly older (mean age 69 years versus 58 years). Presence of human herpesviruses DNA was assessed using commercial PCR assays: herpes simplex virus (HSV) type 1 (HSV-1), type 2 (HSV-2) and varicella-zoster virus (VZV) with RealStar Alpha Herpesvirus PCR kit (altona Diagnostics GmbH, Germany); EBV and human cytomegalovirus (hCMV) with Artus EBV and CMV kits (Qiagen, Germany); and HHV-6, HHV-7 and HHV-8 with the HHV-6, -7 and -8 R-gene kit (Argene, France). TTV DNA was detected with TTV R-gene kit (Argene). We developed a real-time PCR assay amplifying part of the DNA polymerase gene of HVS. Briefly, $10 \mu \mathrm{L}$ of extracted DNA was added to $2 \mu \mathrm{L}$ of FastStart DNA MasterMix (Roche, Germany), $2.4 \mu \mathrm{L}$ of $25 \mathrm{mM}$ magnesium chloride, $0.2 \mu \mathrm{L}$ of $20 \mu \mathrm{M}$ forward and reverse primers (5'-TTAAAATAAATGTGCCTACAATT-3' and 5'-TGCTTATTTGTAGCTTTCATT-3', respectively),

@ERSpublications

There is a high prevalence of human herpesviruses in lung samples of IPF patients but this does not differ from controls, neither regarding prevalence, viral load levels nor co-infection rates. Herpesvirus saimiri DNA is not detected in any lung samples. https://bit.ly/2ZrKiDJ

Cite this article as: Le Hingrat Q, Ghanem M, Cazes A, et al. No association between human herpesvirus or herpesvirus saimiri and idiopathic pulmonary fibrosis. ERJ Open Res 2020; 6: 002432020 [https://doi.org/10.1183/23120541.00243-2020]. 


\begin{tabular}{|c|c|c|c|c|c|c|c|c|c|c|c|c|c|c|c|}
\hline Patient ID & Sex & $\begin{array}{c}\text { Age } \\
\text { years }\end{array}$ & $\begin{array}{c}\text { Tobacco } \\
\text { exposure" }\end{array}$ & $\begin{array}{c}\text { Environmental } \\
\text { exposure }{ }^{\Uparrow}\end{array}$ & Condition & HRCT pattern & Histology & IPF treatment & HSV-1 HSV-2 VZV & $\begin{array}{l}\text { hCMV viral } \\
\text { load } \\
\text { (log } 10 \text { copies } \\
\text { per } 10^{6} \\
\text { cells) }\end{array}$ & $\begin{array}{l}\text { EBV viral } \\
\text { load } \\
\text { ( } \log _{10} \text { copies } \\
\text { per } 10^{6} \\
\text { cells) }\end{array}$ & 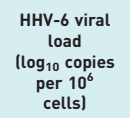 & HHV-7 HHV-8 HVS & $\begin{array}{l}\text { TTV viral } \\
\text { load } \\
\text { (log } 10 \text { copies } \\
\text { per } 10^{6} \\
\text { cells) }\end{array}$ & $\begin{array}{l}\text { Viral DNA } \\
\text { detected }\end{array}$ \\
\hline$\# 01$ & Male & 55 & 1 & 0 & IPF & UIP & UIP & None & & & 3.1 & & & ND & EBV \\
\hline 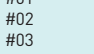 & $\begin{array}{l}\text { Male } \\
\text { Male }\end{array}$ & $\begin{array}{l}44 \\
49\end{array}$ & $\begin{array}{l}0 \\
1\end{array}$ & $\begin{array}{l}0 \\
0 \\
0\end{array}$ & $\begin{array}{l}\text { IPF } \\
\text { IPF }\end{array}$ & $\begin{array}{c}\text { UIP } \\
\text { Possible UIP }\end{array}$ & $\begin{array}{c}\text { UIP } \\
\text { Probable UIP }\end{array}$ & $\begin{array}{l}\text { Pirfenidone } \\
\text { None }\end{array}$ & & & $\begin{array}{l}. .1 \\
.3 .3 \\
2.4\end{array}$ & 2.4 & & 3.1 & $\begin{array}{c}\text { EBV } \\
\text { EBV, HHV- } 6,\end{array}$ \\
\hline$\# 04$ & Male & 62 & 1 & 0 & IPF & UIP & UIP & $\begin{array}{l}\text { Pirfenidone and } \\
\text { prednisone } \\
\text { (exacerbation) }\end{array}$ & & & & 2.6 & & & $\begin{array}{c}\text { TTV } \\
\text { HHV-6 }\end{array}$ \\
\hline$\# 05$ & Male & 66 & 1 & 1 & IPF & UIP & UIP & $\begin{array}{l}\text { Prednisone } \\
\text { Pre }\end{array}$ & & & & 2.1 & & 2.1 & HHV-6, TTV \\
\hline$\# 06$ & Male & 68 & 1 & 0 & IPF & Probable UIP & UIP + Exacerbation & Pirfenidone & & & & & & 2.5 & TTV \\
\hline$\# 07$ & Male & 58 & 0 & 0 & IPF & UIP & UIP & None & & & 2.4 & & & 2.9 & EBV, TTV \\
\hline $\begin{array}{l}\# 08 \\
\# 09\end{array}$ & $\begin{array}{l}\text { Male } \\
\text { Male }\end{array}$ & $\begin{array}{l}74 \\
50\end{array}$ & $\begin{array}{l}1 \\
1\end{array}$ & $\begin{array}{l}1 \\
0\end{array}$ & $\begin{array}{l}\text { IPF } \\
\mathrm{IPF}\end{array}$ & $\begin{array}{l}\text { Possible UIP } \\
\text { Possible UIP }\end{array}$ & $\begin{array}{l}\text { UIP } \\
\text { UIP }\end{array}$ & $\begin{array}{l}\text { Nintedanib } \\
\text { None }\end{array}$ & & & $\begin{array}{l}3.3 \\
2.0\end{array}$ & 2.2 & & 3.4 & $\begin{array}{l}\text { EBV } \\
\text { EBV, HHV-6, }\end{array}$ \\
\hline$\# 10$ & Male & 61 & 1 & 0 & IPF & Possible UIP & UIP & Nintedanib & & & 3.1 & 2.4 & & & EBV, HHV-6 \\
\hline$\# 11$ & Male & 57 & 1 & 1 & IPF & Possible UIP & & Pirfenidone & & & 3.9 & & + & & EBV, HHV-7 \\
\hline$\# 12$ & Male & 51 & 1 & 0 & IPF & UIP & UIP + Exacerbation & None & & 1.6 & & 2.0 & & 2.7 & $\begin{array}{l}\text { hCMV } \\
\text { Hov }\end{array}$ \\
\hline \#13 & Male & 60 & 1 & 1 & IPF & UIP & UIP & Pirfenidone & & & 2.7 & 1.9 & & 1.8 & $\begin{array}{l}\text { ABV, HHV } 6 \text {, } \\
\text { ETV }\end{array}$ \\
\hline$\# 14$ & Male & 61 & 0 & 0 & IPF & Possible UIP & UIP & Pirfenidone & & & & 1.7 & & 2.7 & HHV-6, TTV \\
\hline$\# 15$ & Male & 64 & 1 & 1 & IPF & & UIP + Exacerbation & Pirfenidone & & & 3.8 & & & 1.7 & EBV, TTV \\
\hline $\begin{array}{l}\# 16 \\
\# 17\end{array}$ & $\begin{array}{l}\text { Female } \\
\text { Male }\end{array}$ & $\begin{array}{l}46 \\
57\end{array}$ & $\begin{array}{l}0 \\
1\end{array}$ & $\begin{array}{l}1 \\
1\end{array}$ & $\begin{array}{l}\text { IPF } \\
\text { IPF }\end{array}$ & $\begin{array}{l}\text { Possible UIP } \\
\text { UIP }\end{array}$ & $\begin{array}{c}\text { UIP } \\
\text { UIP+Exaceration }\end{array}$ & $\begin{array}{l}\text { Pirfenidone } \\
\text { Nintedanib }\end{array}$ & & 58 & & 2.2 & & 75 & HHV-6 \\
\hline$\# 18$ & Male & 58 & 1 & 0 & IPF & UIP & Or Thactivaturi & Pirfenidone & & & 2.9 & 2.3 & + & 2.2 & $\begin{array}{l}\text { HHV - } 6 \text {, TTV } \\
\text { EBV , HHV } 6 \text {. }\end{array}$ \\
\hline$\# 19$ & Female & 50 & 1 & 0 & IPF & UIP & UIP + Exacerbation & Pirfenidone & & & 0.3 & 1.8 & + & 3.8 & 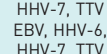 \\
\hline$\# 21$ & Male & 69 & 0 & 0 & Adenocarcinoma & NA & NA & NA & & & & 3.2 & & 2.3 & HHV-6, TTV \\
\hline$\# 22$ & Female & 71 & 1 & 0 & Adenocarcinoma & NA & NA & NA & & & 2.9 & & & 3.8 & EBV, TTV \\
\hline $\begin{array}{l}\# 23 \\
\# 24\end{array}$ & $\begin{array}{l}\text { Female } \\
\text { Female }\end{array}$ & $\begin{array}{l}77 \\
73\end{array}$ & $\begin{array}{l}1 \\
0\end{array}$ & $\begin{array}{l}0 \\
0\end{array}$ & $\begin{array}{l}\text { Adenocarcinoma } \\
\text { Epidermoid carcinoma }\end{array}$ & $\begin{array}{l}\text { NA } \\
\text { NA }\end{array}$ & $\begin{array}{l}\text { NA } \\
\text { NA }\end{array}$ & $\begin{array}{l}\text { NA } \\
\text { NA }\end{array}$ & & & 40 & & + & $\begin{array}{l}3.0 \\
1.9\end{array}$ & $\begin{array}{l}\text { TTV } \\
\text { EBV HHV-7. }\end{array}$ \\
\hline$\# 25$ & Male & 52 & 1 & 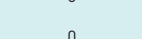 & Adenncarcinoma & $\mathrm{NA}$ & $N A$ & $N A$ & & 18 & & & & 30 & TTV \\
\hline$\# 26$ & Male & 71 & 2 & 0 & $\begin{array}{l}\text { Aenocarnoma } \\
\text { Adenocarcinoma }\end{array}$ & NA & NA & NA & & & & 2.7 & & $\begin{array}{l}2.0 \\
2.2\end{array}$ & HHV-6, TTV \\
\hline \#27 & Female & 68 & 2 & 0 & Epidermoid carcinoma & NA & NA & NA & & & 3.0 & & & 2.2 & EBV, TTV \\
\hline$\# 28$ & Male & 60 & 1 & 0 & $\begin{array}{c}\text { COPD/ } \\
\text { emphysema }\end{array}$ & NA & NA & NA & & & 2.6 & 2.8 & & 2.4 & $\begin{array}{l}\text { EBV, HHV-6, } \\
\text { TTV }\end{array}$ \\
\hline \#29 & Male & 52 & 1 & 1 & $\begin{array}{l}\text { COPD/ } \\
\text { emphysema }\end{array}$ & NA & NA & NA & & & & 2.9 & & 2.5 & HHV-6, TTV \\
\hline
\end{tabular}

Abbreviations: HRCT: high-resolution computed tomography; IPF: idiopathic pulmonary fibrosis; HSV: herpes simplex virus; VZV: varicella-zoster virus; hCMV: human cytomegalovirus; EBV: Epstein-Barr virus; HHV: human herpesvirus; HVS: herpesvirus saimiri; TTV: torque teno virus; UIP: usual interstitial pneumonia; NA: not applicable; ND: not done. \#: current=2, former $=1$, never $=0$; ${ }^{\text {? }}$ yes $=1$, no $=0$. 
$0.2 \mu \mathrm{L}$ of $10 \mu \mathrm{M}$ FAM-probe (5'-FAM-AGACGGGCGCCGCCCACAAAAGC-BHQ1-3') and $5 \mu \mathrm{L}$ of DNase- and RNase-free water. PCR was performed with the following protocol: $8 \mathrm{~min}$ at $95^{\circ} \mathrm{C}$, then 45 amplification cycles $\left(95^{\circ} \mathrm{C}\right.$ for $10 \mathrm{~s}, 48^{\circ} \mathrm{C}$ for $10 \mathrm{~s}$ and $65^{\circ} \mathrm{C}$ for $\left.30 \mathrm{~s}\right)$. Positive controls consisted of dilutions of HVS strain C488 (ATCC VR-1414) viral stock, ranging from 2000 to $0.00250 \%$ tissue culture infective dose. Human albumin gene was amplified to normalise number of viral DNA copies to cell input [11]. Prevalence of viral infections in IPF and control samples were compared using the Mann-Whitney and Fishers exact tests, with a significance level defined as p-value below 0.05.

At least one human herpesvirus DNA was detected in 26 out of 28 (93\%) lung samples, with no difference between IPF patients $(n=18 / 19)$ and controls $(n=8 / 9 ; p=1.00)$ (table 1$)$. HSV-1, HSV-2, VZV and HHV-8 DNA were not detected in any sample. hCMV DNA was detected in two out of 19 (10.5\%) IPF samples and in one out of nine $(11.1 \%)$ control samples $(p=1.0)$. HHV-6 was detected in 12 out of $19(63.2 \%)$ IPF samples and in four out of nine $(44.4 \%)$ control samples $(\mathrm{p}=0.43)$, and, among HHV6-positive biopsies, median viral load was lower for IPF than for controls (2.2 and $2.9 \log _{10}$ copies per $10^{6}$ cells, respectively; $\mathrm{p}=0.004)$. EBV DNA was detected in 12 out of 19 (63.2\%) IPF samples and in four out of nine $(44.4 \%)$ control samples $(\mathrm{p}=0.43)$, and median EBV viral load did not differ between IPF and controls (3.00 and $2.95 \log _{10}$ copies per $10^{6}$ cells, respectively; $\mathrm{p}=0.72$ ). The mean number of human herpesvirus DNAs was 1.53 in IPF patients and 1.11 in controls $(\mathrm{p}=0.10)$. The rate of human herpesvirus co-infections did not significantly differ between IPF and controls $(n=9 / 19$ and $n=2 / 9$, respectively, $p=0.25)$. TTV DNA was detected in 12 out of 18 (66.7\%) IPF samples and nine out of nine control samples ( $\mathrm{p}=0.07)$, and median TTV viral load did not differ between both groups (2.70 versus $2.40 \log _{10}$ copies per $10^{6}$ cells; $\mathrm{p}=0.70$ ). Interestingly, TTV DNA was detected among all IPF patients presenting an episode of acute exacerbation (5/5 patients). HVS DNA was not detected in any lung samples.

In this study, we found a high prevalence of human herpesviruses, with an expression of at least one human herpesvirus in $93 \%$ of samples, and no difference in prevalence of viral infections between IPF patients and controls. This is concordant with the high prevalence of human herpesviruses in the general population. EBV and HHV-6 were the most frequently identified herpesviruses.

Previous studies reported a higher expression of EBV and/or HHV-8 in IPF patients [3, 5-]. However, those studies were performed prior to the results of the PANTHER-IPF study [12]. Samples were obtained from patients frequently treated with corticosteroids or immunosuppressive therapy that may have allowed reactivation of latent herpesviruses. In our study, most of our patients were not receiving corticosteroids or immunosuppressive therapy, with only two patients receiving low-dose prednisone at the time of lung sampling. Levels of immunosuppression in IPF patients were similar to controls, as emphasised by the similar TTV DNA levels. Moreover, as previously reported, TTV DNA was always detected in patients presenting an acute exacerbation of IPF at the time of lung transplantation [10]. Compared with previous studies, we reported a higher prevalence of human herpesviruses infections in control patients $[3,5,13]$. This may be partly due to differences with previous control populations, including a higher median age of control patients in our study, but it is probably mainly explained by the higher sensitivity of specific PCR assays compared with hybridisation assays, or to immunohistochemistry that can only detect active infections $[3,5]$.

We did not detect HVS DNA in any lung sample, suggesting that HVS is not involved in IPF pathogenesis, a result consistent with our current knowledge on this virus. However, these results differ from those of FolCIK et al. [9], who detected HVS DNA in all IPF samples, using a hybridisation assay.

This study has several limitations, notably the limited sample size, a slight imbalance in sex ratio and age, and our inability to formally differentiate latent and productive infections with PCR assays. However, the similar prevalence of human herpesvirus infections and the absence of HVS DNA in controls and IPF patients do not support a specific role for those viruses in IPF.

Quentin Le Hingrat $\oplus^{1,2,5}$, Mada Ghanem ${ }^{3,5}$, Aurélie Cazes ${ }^{4}$, Benoit Visseaux $\oplus^{1,2}$, Gilles Collin ${ }^{1,2}$, Diane Descamps ${ }^{1,2}$, Charlotte Charpentier ${ }^{1,2}$ and Bruno Crestani ${ }^{3}$

${ }^{1}$ Université de Paris, INSERM UMR 1137 IAME, Paris, France. ${ }^{2}$ AP-HP, Hôpital Bichat-Claude Bernard, Laboratoire de Virologie, Paris, France. ${ }^{3}$ AP-HP, Hôpital Bichat-Claude Bernard, Service de Pneumologie, Centre de référence des maladies pulmonaires rares, Université de Paris, INSERM UMR1152, Paris, France. ${ }^{4}$ AP-HP, Hôpital Bichat-Claude Bernard, Service d'Anatomo-cytopathologie, Université de Paris, INSERM UMR1152F Paris, France. ${ }^{5}$ These authors contributed equally.

Correspondence: Bruno Crestani, Hôpital Bichat-Claude Bernard, Service de Pneumologie, Centre de référence des maladies pulmonaires rares, 46 Rue Henri Huchard, 75018 Paris, France. E-mail: bruno. crestani@aphp.fr 
Received: 30 June 2020 | Accepted: 9 July 2020

Conflict of interest: Q. Le Hingrat has nothing to disclose. M. Ghanem has nothing to disclose. A. Cazes has nothing to disclose. B. Visseaux has nothing to disclose. G. Collin has nothing to disclose. D. Descamps reports personal fees for advisory board participation from ViiV Healthcare, Gilead Sciences, MSD and Janssen-Cilag, outside the submitted work. C. Charpentier reports personal fees from Gilead, personal fees from MSD, personal fees from ViiV, personal fees from Janssen, outside the submitted work. B. Crestani reports speaker honoraria and support to attend a congress from AstraZeneca; grants, speaker honoraria support to attend a congress from Boehringer Ingelheim and Roche; speaker honoraria, honoraria for consultancy and support to attend a congress from Sanofi; personal fees for membership of an advisory board from Genzyme; and personal fees for membership of an advisory board and support to attend a congress from BMS, all outside the submitted work.

\section{References}

Richeldi L, Collard HR, Jones MG. Idiopathic pulmonary fibrosis. Lancet 2017; 389: 1941-1952.

2 Moore BB, Moore TA. Viruses in idiopathic pulmonary fibrosis. Etiology and exacerbation. Ann Am Thorac Soc 2015; 12: Suppl. 2, S186-S192.

3 Calabrese F, Kipar A, Lunardi F, et al. Herpes virus infection is associated with vascular remodeling and pulmonary hypertension in idiopathic pulmonary fibrosis. PLoS One 2013; 8: e55715.

4 Tang Y-W, Johnson JE, Browning PJ, et al. Herpesvirus DNA is consistently detected in lungs of patients with idiopathic pulmonary fibrosis. J Clin Microbiol 2003; 41: 2633-2640.

5 Pulkkinen V, Salmenkivi K, Kinnula VL, et al. A novel screening method detects herpesviral DNA in the idiopathic pulmonary fibrosis lung. Ann Med 2012; 44: 178-186.

6 Stewart JP, Egan JJ, Ross AJ, et al. The detection of Epstein-Barr Virus DNA in lung tissue from patients with idiopathic pulmonary fibrosis. Am J Respir Crit Care Med 1999; 159: 1336-1341.

7 Kelly BG, Lok SS, Hasleton PS, et al. A rearranged form of Epstein-Barr virus DNA is associated with idiopathic pulmonary fibrosis. Am J Respir Crit Care Med 2002; 166: 510-513.

8 Vannella KM, Luckhardt TR, Wilke CA, et al. Latent herpesvirus infection augments experimental pulmonary fibrosis. Am J Respir Crit Care Med 2010; 181: 465-477.

9 Folcik VA, Garofalo M, Coleman J, et al. Idiopathic pulmonary fibrosis is strongly associated with productive infection by herpesvirus saimiri. Mod Pathol 2014; 27: 851-862.

10 Wootton SC, Kim DS, Kondoh Y, et al. Viral infection in acute exacerbation of idiopathic pulmonary fibrosis. Am J Respir Crit Care Med 2011; 183: 1698-1702.

11 Désiré N, Dehée A, Schneider V, et al. Quantification of human immunodeficiency virus type 1 proviral load by a TaqMan real-time PCR Assay. J Clin Microbiol 2001; 39: 1303-1310.

12 Idiopathic Pulmonary Fibrosis Clinical Research Network, Raghu G, Anstrom KJ, et al. Prednisone, Azathioprine, and N-Acetylcysteine for Pulmonary Fibrosis. N Engl J Med 2012; 366: 1968-1977.

13 Lasithiotaki I, Antoniou KM, Vlahava V-M, et al. Detection of herpes simplex virus type-1 in patients with fibrotic lung diseases. PLoS One 2011; 6: e27800. 